\title{
Vejledning af læger under uddannelse
}

\author{
Charlotte Søjnæs, Institut for Psykologi og Uddannelsesforskning, Roskilde \\ Universitet \& Center for Klinisk Uddannelse, Region Hovedstaden
}

Berit Eika, Gitte Wichmann-Hansen, Kirsten Hofgaard Lycke, Gunnar Handal.

Vejledning af læger under uddannelse

Munksgaard, 2015

139 sider

ISBN: 978-87-628-0419-7

Berit Eika, prorektor for uddannelse på Århus Universitet, Gitte Wichmann-Hansen, forskningsleder ved Center for Undervisning og Læring på Århus Universitet, Kirsten Hofgaard Lycke og Gunnar Handal, begge professor emeritus ved fagområdet for Universitetspædagogik på Institut for pædagogik på Universitetet i Oslo, har sammen skrevet en kærkommen håndbog om vejledning af læger, som er et særligt pædagogisk område, der ikke findes meget handlingsanvisende litteratur om eller lærebøger i. Bogen har otte korte kapitler, der alle afsluttes med referencer til relevant litteratur. I det hele taget er bogen pædagogisk opbygget med klare introduktioner til hvert kapitel, faktabokse og eksempler. Sproget flyder let, og det er ikke til at se, at der er tale om fire forskellige forfattere - bogen fremstår flot sammenskrevet.

Formålet med bogen er at opnå bedre effekt af både formelle vejledningssamtaler og af den mere uformelle daglige kliniske vejledning. Målgruppen er først og fremmest nye og erfarne vejledere engageret i uddannelse af læger, men forfatterne skriver, at beslutningstagere også kan have udbytte af at læse bogens argumenter for at kunne skabe de nødvendige strukturer, der giver ressourcer til vejledningsopgaverne i dagligdagen. Endelig at yngre læger også kan have en fordel af at have viden om, hvad der ligger bag vellykkede vejledningsforløb. Bogen anbefales endvidere til andre sundhedsuddannelser. Det er altså en håndbog, der vil mange ting og har meget på hjertet. I forordet står der:

"Vejledning rummer potentielt en stor mulighed for at forbedre yngre lægers uddannelse [...] Bogen repræsenterer en tænkning omkring vejledning, som fordrer, at vejledning får en mere synlig, prioriteret og integreret plads i det daglige kliniske arbejde. Tænkningen tager dels sit udgangspunkt i viden og teorier om læring, dels i mange års praktisk erfaring med udvikling af undervisning og vejledning og dels et ideal om, at kvalitet i uddannelse og patientbehandling nok er forskelligartede aktiviteter med forskellige mål, men alligevel bør hænge tæt sammen. Når man tilgodeser den yngre læges uddan- 
nelsesbehov i konkrete situationer, tilgodeser man også patientbehandling i fremtiden."

Dette normative udgangspunkt gennemsyrer bogen fra start til slut. Det er tydeligt, at der skrives til et felt, hvor der er en praksis, der skal skubbes til, og det gør forfatterne på en sympatisk, respektfuld og engageret facon, hvor de bruger deres forskellige erfaringer til at tilbyde teoretiske perspektiver på vejledning og læring samt redskaber til, hvordan samtaler konkret kan gennemføres i praksis.

Bogens læringsteoretiske udgangspunkt er kognitivt og sociokulturelt, hvilket er i fin overensstemmelse med feltets egen forståelse, som traditionelt har været kognitivt domineret, men hvor betydningen af sociale og kontekstmæssige aspekter af læring nu også i stigende grad er i fokus. Vejledningsbegrebet i bogen sigter mod de formelle samtaler, der ifølge forfatterne bør suppleres med det, de kalder for reflekterende vejledning. Vejledningen tager sit afsæt i praktiske situationer og i de handlinger, der er knyttet dertil, samt formulerer begrundelser for handlingerne ud fra de kundskaber, erfaringer og værdier, man har med sig. Her får vejledning karakter af medtænkning frem for kontrol eller bedømmelse. Det er også her forfatterne bevæger sig længere væk fra praksis og hermed introducerer et andet perspektiv på vejledningens funktion, der potentielt kan skabe udvikling.

Læses bogen af praktikere (læger der vejleder andre læger) med fokus på anvendelse, opstår der nogle udfordringer. Som nævnt indledningsvis vil forfatterne bag bogen mange ting på én gang. Det er både vigtigt og relevant at kvalificere den vejledning, der foretages af læger og styrke en relativt underbelyst og underprioriteret uddannelsesaktivitet, men det er også her, at bogen på nogle måder placerer sig i et mellemleje, hvor den ikke direkte kan anvendes af travle kliniske vejledere, da den niveaumæssigt placerer sig et stykke fra nuværende praksis ( $\mathrm{fx}$ med referencer til Habermas) og forudsætter, at de formelle krav fra Sundhedsstyrelsens side overholdes - hvilket slet ikke kan forudsættes. Det betyder, at mange af de vejledere, bogen har som hovedmålgruppe, faktisk starter på et væsentligt lavere udgangspunkt, og for nogle vejlederes vedkommende kan der være lang vej, til opfyldelse af blot de formelle krav.

Endvidere er det centralt for bogens opbygning, at der tages udgangspunkt i at bygge oven på de tre formaliserede vejledningssamtaler, der består af en introduktionssamtale, en justeringssamtale og en evalueringssamtale. Problemet her er, at det ikke længere formelt er gældende. De obligatoriske samtaler blev erstattet i 2008 (VEJ nr 9586 af 14/07/2008) af individuelle uddannelsesplaner, som karakteriserer et fokusskifte fra Sundhedsstyrelsens og Ministeriet for Sundhed og Forebyggelses side fra en uddannelsestænkning, hvor alle yngre læger skulle det samme mod en mere individualiseret uddannelse, hvor den enkelte yngre læges behov, erfaringer, værdier og interesser står i centrum. I forhold til den logik, var det ikke længere meningsfuldt at tale om, at alle skulle have tre samtaler. Nogle yngre læger skulle måske kun have to samtaler, mens nogle skulle have fem - med udgangspunkt i den individuelle ud- 
dannelsesplan. I praksis er betydningen måske ikke så stor. Mange uddannelsesansvarlige læger kender ikke den gældende vejledning og afdelingerne benytter stadigvæk de tre formaliserede samtaler - og der rammer bogen jo plet. Det ville dog have været interessant at se, hvad forfatterne ville have fået ud af at have en ramme som individuelle uddannelsesplaner som grundlag for bogens opbygning og den reflekterende vejledning som forfatterne fremhæver, ville ligge i fin forlængelse af individuelle uddannelsesplaner med udgangspunkt i det enkelte subjekt. Netop det at operationalisere den individuelle uddannelsesplan og få sat den i spil i de kliniske afdelinger er en stor udfordring i dagligdagen for nogle vejledere.

Bogens mange konkrete eksempler på samtaler er en stor hjælp til vejlederne. Man kunne have ønsket, at de anvendte eksempler havde bredt sig over flere af lægens roller. I bogen er det medicinsk faglige spørgsmål, der eksemplificeres (lægerollen medicinsk ekspert), mens de øvrige roller ikke inddrages. Eksempler med rollerne som fx kommunikator, samarbejder og måske især professionel ville kunne have hjulpet vejlederne der, hvor de i det daglige kommer mest til kort og kunne have illustreret nogle af bogens vejledningsmæssige pointer på eksemplarisk vis. Omvendt fungerer bogen som en stor inspirationskilde og et væsentligt bidrag til kvalificering af vejledningsopgaven blandt læger.

Bogen kan også anbefales til undervisere og konsulenter, der arbejder med vejledning inden for andre hovedområder, da den giver mange nyttige anvisninger og råd med på vejen om emner som 'Vejledning i og med grupper', 'Vejlederens redskaber i samtalen' og 'Planlægning af vejledning' som eksempler på kapitler, der kan have en bred universitetspædagogisk interesse.

Bogen kan endvidere danne afsæt for en lang række diskussioner om vejledningens funktion, indhold og form og giver et solidt grundlag for en lang række aktiviteter knyttet til uddannelse af vejledere - en stor tak til de fire forfattere for dette bidrag! 